\title{
Obstructive Pulmonary Embolus from Metastatic Renal Cell Carcinoma
}

Madison S. Hill ${ }^{1}$, Zachary N. Kon ${ }^{2}$, and Michael W. Phelan ${ }^{1}$

${ }^{1}$ University of Maryland School of Medicine

${ }^{2}$ Department of Cardiothoracic Surgery Northwell Health Manhasset NY

January 27, 2022

\section{Hosted file}

RCC cardiac surgery phelan edits.docx available at https://authorea.com/users/457611/ articles/554327-obstructive-pulmonary-embolus-from-metastatic-renal-cell-carcinoma

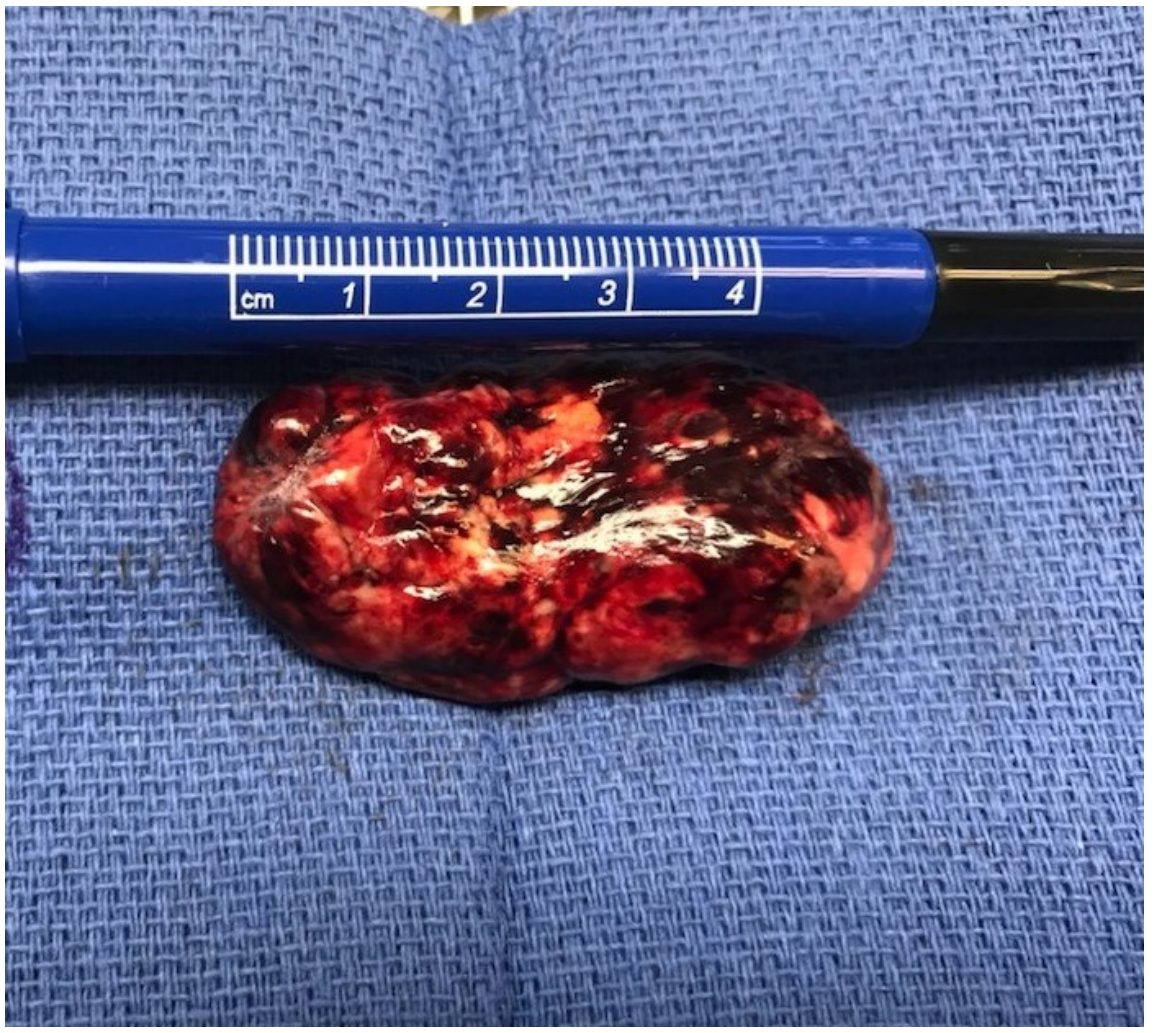



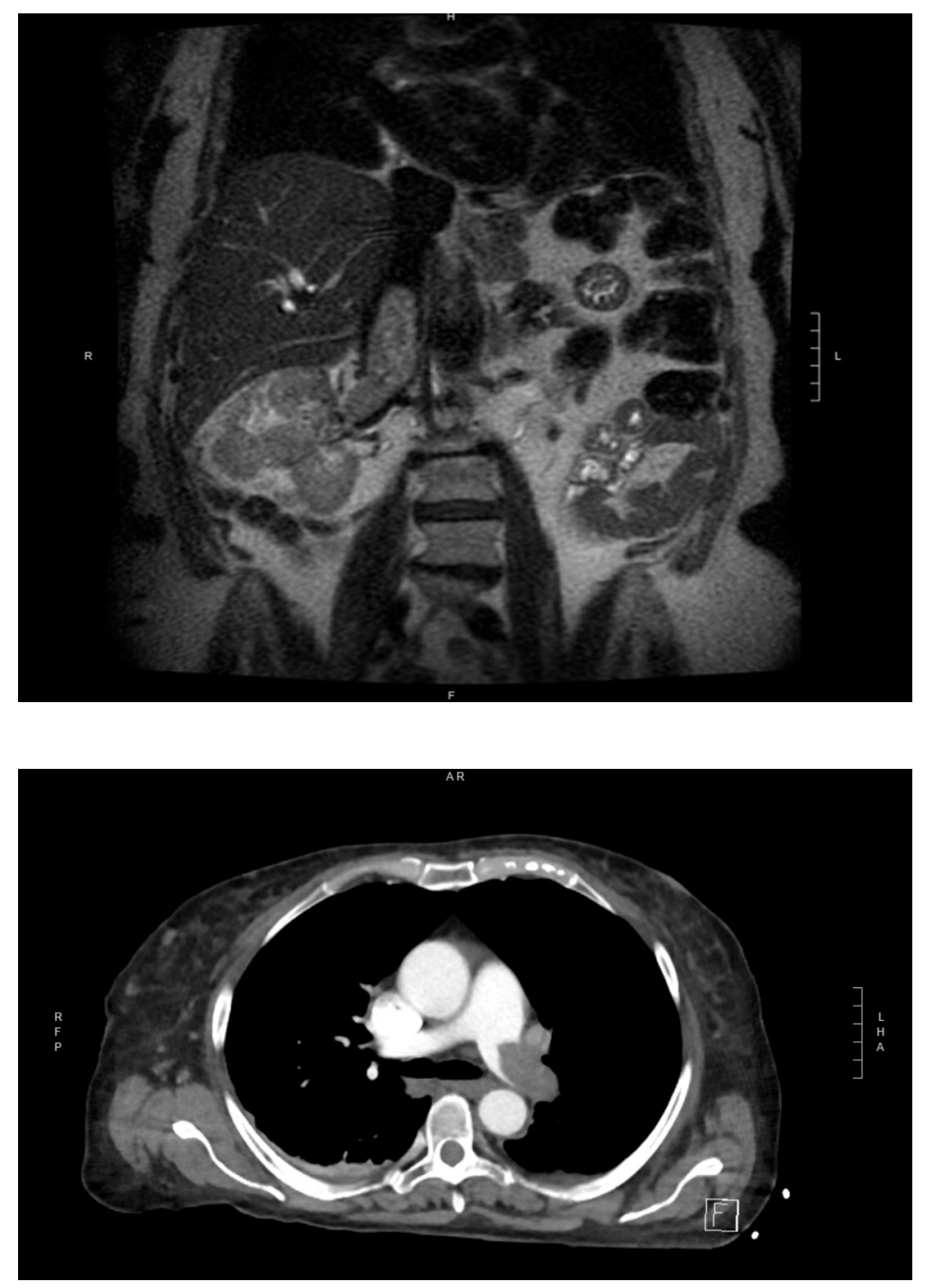